\title{
High-impact hate speech by persons of authority: A lower threshold needed?
}

\author{
JUDIT BAYER*
}

Department of Communication, Budapest Business School, Faculty of International Management and Business, Budapest, Hungary

\section{ORIGINAL RESEARCH PAPER}

Received: February 11, 2020 • Revised manuscript received: September 21, 2020 • Accepted: September 23, 2020

Published online: July 29, 2021

(c) 2020 The Author(s)

\begin{abstract}
This paper discusses a global trend in the approach to hate speech. It describes how the international human rights organisations are recently addressing the dynamics of hate speech and how academic thinking is stretching the framework of the justification of hate speech regulations. This work analyses the aspect of cause and effect in the light of the role of the speaker; examining the academic argument that content expressed by public figures of authority have a higher impact, in particular in the context of the digital media ecosystem, with a social media dominance.
\end{abstract}

\section{KEYWORDS}

hate speech, social media, political communication, speech act theory

\footnotetext{
*Corresponding author. E-mail: bayer.judit@uni-bge.hu

The present paper was authored in the framework of the MTA-ELTE Lendület SPECTRA Research Group (Social prerequisites for the effective fight against bias-motivated crimes through criminal law and minority rights protection, contract number: LP2018-9/2018).
} 
'Beruft dich die hohe Behörde in ein Amt, so wisse: jeder Aufstieg in der Stufe der Ämter ist nicht ein Schritt in die Freiheit, sondern in die Bindung. Je höher das Amt, desto tiefer die Bindung. Je größer die Amtsgewalt, desto strenger der Dienst. Je stärker die Persönlichkeit, desto verpönter die Willkür.'

\section{INTRODUCTION}

The highly discussed controversy around hate speech $^{2}$ appears to have culminated in a global discussion, where the opposing sides have found themselves getting closer to each other after an initial deconstruction of the elements of their argumentations. This process has been fuelled by the massive changes in public and political communication in the 'social media age'. Politicians are able to communicate with their voters without the moderating effect of traditional media editors and have enjoyed the instant feedback from their constituencies. The possibility of feedback provides the false sense of interaction between peers whereas the communication is fully controlled by the speaker.

This paper starts by briefly discussing the global human rights documents that demonstrate a global understanding and agreement in the regulation of hate speech. The agreement is limited to a rather narrow area of hate speech. The important aspects of the new approaches to hate speech will then be highlighted by representative recent documents, a result of a global (UN) or regional $(\mathrm{CoE})$ consensus to address this issue. Reactions to this new trend will be investigated in both academic theories and arguments and the paper concludes by exploring these arguments in the light of existing jurisprudence and scrutinises the cause and effect relationship between speech and action, when the speaker is a person of authority.

\section{THE INTERNATIONAL LEGAL DOCUMENTS}

The first global human rights document, the Universal Declaration of Human Rights (hereinafter: UDHR) in 1948 declared both the protection of freedom of expression and the prohibition of incitement to discrimination. It declared that all rights shall be enjoyed without distinction of any kind, such as race, colour, sex, language, religion, political or other opinion, national or social origin, property, birth or other status. ${ }^{3}$ This document was not obligatory for states but became an instructive standard in international human rights law.

Member states showed no receptiveness for a binding human rights convention with a general scope. Nonetheless, the most pressing problem of this historical period was addressed by a binding global human rights treaty- the Convention on the Prevention and Punishment of the Crime of Genocide, which was adopted unanimously by the United Nations General Assembly in 1948. Article III.c. of this Convention provides that direct and public incitement to commit

\footnotetext{
${ }^{1}$ English translation: 'If the high Authority appoints you to an office, know this: every step upward on the ladder of offices is not a step into freedom but into bondage. The higher the office, the tighter the bondage. The greater the power of the office, the stricter the service. The stronger the personality, the less self-will.' Hesse (2012). Translated by Richard and Clara Winston.

${ }^{2}$ For the purposes of this paper, I will use the expression 'hate speech' in its every day, broad meaning which also includes those expressions which do not reach the criminal threshold. I will use the adjectives 'illegal' or 'criminal' or use 'incitement to hatred' whenever I specifically mean to designate the legally relevant, prohibited forms of hates peech.

${ }^{3}$ Universal Declaration of Human Rights in 1948, Article 19, Article 7 and Article 2.
} 
genocide shall be punishable as a crime under international law and states undertook to prevent and punish such crimes. Compared to the general notion of hate speech and incitement to hatred, genocide is a very narrowly and precisely term as it requires the intention to destroy, in whole or in part, a national, ethnical, racial or religious group (Article II). This formulation was inspired by the legal foundation of the International Military (Nuremberg) Tribunal, which convicted Julius Streicher, publisher of the anti-Semitic weekly 'Der Stürmer' for incitement and subsequently Otto Dietrich, who was responsible for the press section in Goebbels' propaganda ministry between 1938 and $1945 .{ }^{4}$ Other states, such as Poland and Hungary also carried out procedures and convicted war criminals for incitement to genocide directly after the war. ${ }^{5}$

On the basis of the Genocide Convention, incitement to genocide has only been established in the well-documented case of the Rwandan genocide, where radio broadcasts instigated the civil population against the minority ethnic group. This ethnic cleansing also received some attention from the scientific community. ${ }^{6}$

The cause and effect relationship was the central focus of the procedure at the International Tribunal for Yugoslavia. Vojislav Šešelj called for the expulsion of the Croats and Albanians in front of a large audience., the Court of First Instance found that the content of a speech in November 1991s could not be established beyond reasonable doubt and it could not establish that this speech was in causal relation with the subsequent ethnic cleansing. ${ }^{7}$ The Appeal Court found that his words 'rivers of blood' would follow a Bosnian declaration of independence and 'to clean the left bank of the Drina' were clearly inflammatory but noted the lapse of time between the expressions and the war crimes committed. The court agreed that the causal relationship did not stand in relation to these statements. However, in relation to statements a year later in 1992, the Appeal Court overruled the first judgement and found that the words of Seselj 'you will promptly get rid of the remaining Croats in your village and the surrounding villages' were followed by a mass exodus of Croatians and other non-Serbians from the town Hrtkovci. Therefore, the court found that these expressions 'denigrated and violated the right to security' of members of the Croatian population. It also weighed the inaction of the local authorities. Finally, it found Seselj criminally responsible for instigating deportation, persecution, through forcible displacement and transfer as crimes against humanity. ${ }^{8}$

In a few, less documented cases of intergroup atrocities, hate speech has been similarly 'uttered in service of a widespread or systematic attack against a civilian population', for example in Kenya, Cote d'Ivoire, Sudan and Iran. However, these did not reach the international courts. ${ }^{9}$ The case of Myanmar is significantly better documented and is currently at the International Court of Justice. ${ }^{10}$

\footnotetext{
${ }^{4}$ Timmermann (2006) 1-30. See also: IMT (1947) link 1.

${ }^{5}$ Bárd (2020).

${ }^{6}$ Yanagizawa-Drott (2014). See also: Melvern (2001) and Maravilla (2018) and DesForges (1999).

${ }^{7}$ IRMCT (2016) link 2.

${ }^{8}$ IRMCT (2016) link 2.

${ }^{9}$ Gordon (2014).

${ }^{10}$ Gambia filed a case against Myanmaratthe ICJ, claiming that Myanmar violated the provisions of the Genocide Convention, on 11 November, 2019.
} 
The next global human rights treaty in chronological order was the International Convention on the Elimination of All Forms of Racial Discrimination (hereinafter: ICERD) of 1965. This prohibits discriminatory speech and action on a significantly broader scale than either the Genocide Convention or the later International Covenant on Civil and Political Rights. It is therefore frequently criticised by advocacy groups. Articles 4 and 6 oblige states to criminalize certain forms of hate speech and the commission of, or incitement to acts of violence against any race, group of persons of another colour or ethnic group; furthermore, states must create the legal and institutional basis to provide effective protection and remedies against any acts of racial discrimination and must provide for reparation and satisfaction for damages suffered as a result of discrimination. ${ }^{11}$

The most relevant international provisions relating to 'hate speech' have been laid down by the International Covenant on Civil and Political Rights (ICCPR) of 1966, entering into force in 1976, especially Article 20 - as interpreted together with Article 19. Its definition is regarded as being sufficiently narrow: The list of protected characteristics is short and closed (national, racial or religious hatred); it requires 'advocacy', that is, an intentional and public promotion of hatred; the advocated 'hatred' is supposed to constitute incitement to discrimination, hostility or violence, i.e. illegal material actions.

The Council of Europe claims to be the first and only international intergovernmental organisation which has adopted an official definition of hate speech, which has no officially agreed definition appearing elsewhere in international human rights documents. ${ }^{12}$ Recommendations No. R (97) 20 on Hate Speech and (97) 21 on the media and the promotion of a culture of tolerance have paved the way for several other specific recommendations on the topic. Its Commission against Racism and Intolerance (ECRI), has also issued meaningful soft instruments, among them Recommendation No. 15. of 2015, ${ }^{13}$ which is of exceptional relevance for our topic. It points at the increasing phenomenon of hate speech being used by some highlevel politicians and recommends alternative forms of remedies. Several international actors observed a global surge in intolerant, racist speech.

Two threads of the new approaches are discussed through the international legal instruments. One focuses on the conditions and limits of legal restrictions whilst the other looks at the symbolic actions of the state and the polity.

The Rabat Plan of Action ${ }^{14}$ draws up a six-part threshold-test to support practical implementation of hate speech prohibitions and to distinguish between offensive, but not punishable expressions and illegal hate speech. The six factors are:

\footnotetext{
${ }^{11}$ For example, by Amnesty International, which urged the Commission to clarify the scope of the respective Article 4a) 'Shall declare an offence punishable by law all dissemination of ideas based on racial superiority or hatred, incitement to racial discrimination, as well as all acts of violence or incitement to such acts against any race or group of persons of another colour or ethnic origin, and also the provision of any assistance to racist activities, including the financing thereof; in particular recommending to include the intent to achieve a prohibited result.

${ }^{12}$ Appendix to Recommendation No. R (97) 20.' According to the Committee of Ministers, hate speech covers all forms of expressions that spread, incite, promote or justify racial hatred, xenophobia, anti-Semitism or other forms of hatred based on intolerance, including intolerance expressed by aggressive nationalism and ethnocentrism, discrimination and hostility against minorities, migrants and people of immigrant origin.'

${ }^{13}$ ECRI General Policy Recommendation $N^{\circ} 15$ on combating hate speech - adopted on 8 December 2015.

${ }^{14}$ Rabat Plan of Action, https://www.ohchr.org/Documents/Issues/Opinion/SeminarRabat/Rabat_draft_outcome.pdf.
} 
1. context

2. speaker

3. intent

4. content and form

5. reach or magnitude of the speech

6. the likelihood of the harm

The particular value of the Rabat Plan of Action lies partly in its legitimacy ${ }^{15}$ and partly in its connectedness to hate speech theory, which is pre-occupied with the effect of the incriminate speech. The factors set out by the Rabat Plan of Action deconstruct the concept of social impact and thereby help to identify the conditions when expressions have a high likelihood to make a harmful impact beyond insult of feelings. This could assist in reform and harmonisation of the legal rules against hate speech within the changed political and media environment.

Among many of the international documents, the UN Strategy and Plan of Action on Hate Speech ${ }^{16}$ expressed concern that the mentioned phenomenon started to threaten democratic values even in established democracies and followed a different path. It set out a complex social and political strategy to fight against intolerance in the form of 13 Key Commitments, without even mentioning legal restrictions. In particular, the prevalence of such speech has extended beyond the boundaries of peripheric, marginal groups and minor media products and entered mainstream public discourse. International organisations have formulated their concern that words expressed by high-level politicians are of higher social impact than everyday, low-value speech, therefore, they repeatedly called upon politicians and public officials to act consciously regarding their duties and their responsibility to improve and maintain social piece and cohesion. ${ }^{17}$ Legal regulation seems incapable to stop this trend. Firstly, the online environment has washed official gatekeeping methods away; the volume of published content has exploded and controlling content have become complicated and of little avail. Political speech enjoys the highest level of constitutional protection. The political power of the speakers may hinder investigation of their expressions and finally, the rhetoric often successfully balances on the verge of criminality, not reaching the high threshold of incitement to hatred. Whether the said rhetoric reaches the threshold of criminal law, its socially damaging effect is thought to be higher than hate speech by ordinary citizens. The research and arguments concerning hate speech by politicians have been accumulating in the past decades and signal a call for re-interpretation of hate speech standards, especially in the light of domestic political and international events. Whether the perceived growth of hostility and social polarisation can be attributed to the phenomenon of political hate speech on the rise needs further empirical research. This article examines this hypothesis from an abstract, theoretical perspective.

\footnotetext{
${ }^{15}$ Parmar (2015).

${ }^{16}$ UN Strategy and Plan of Action on Hate Speech; ECRI General Policy Recommendation No 15 on combating hate speech - adoptedon 8 December 2015.

${ }^{17}$ CERD Recommendation No. 35., ECRI General Policy Recommendation No 15 on combating hate speech - adopted on 8 December 2015, Recommendation No. R (97) 20 on 'Hate Speech'.
} 


\section{RECENT PHILOSOPHICAL APPROACHES ON HOW TO TACKLE HATE SPEECH}

The academic debate, in parallel with the attention of the international human rights bodies around hate speech, has reached new heights in recent decades. The first underlying question has remained whether restricting hate speech is at all necessary? This has been a classical contrast between the United States' exceptionally liberal approach and the Continental, more 'protective' approach. ${ }^{18}$ The second question is, provided that some restriction are acceptable, where should the threshold be for speech limitation.

There is a widely known contrast between the almost uninhibited freedom of expression in the United States, American exceptionalism, ${ }^{19}$ and the regulated freedom of the European continent where, in most states, incitement to hatred is criminalised.

The American free speech tradition rejects restrictions to speech along certain 'community standards', because it would inappropriately enable 'a single community use the authority of the state to confine speech within its own notions of propriety'. ${ }^{20}$ This is exceptionalism because its alleged reason is the heterogeneity of the American society. Post notes, and there seems to be a paradox here, that this concept is inherently unstable, because speech that violates community norms of civility is perceived as irrational and coercive and hence as incompatible with public deliberation. Thus first amendment doctrine suspends legal enforcement of the very norms that make rational deliberation possible. ${ }^{21}$

Interestingly, this argumentation is rather similar to the one offered by the European Court of Human Rights, which often relies on Article 17 of the ECHR, ${ }^{22}$ the abuse of rights provision to reject applications that call for the protection of denying facts of the Holocaust (Garaudy $v$. France, Honsik v. Austria, Marais v. France, Williamson v. Germany, Pastörs v. Germany) or giving promotion to negationism through a controversial comedy (M'BalaM'Bala v. France ${ }^{23}$ ), as well as promoting white supremacy (Glimmerveen and Haqenbeek $v$. the Netherlands ${ }^{24}$ ), or religious hate (Norwood v. UK, Belkacem v. Belgium $\left.{ }^{25}\right){ }^{26}$

An attractive clarification in this dispute is offered by Heinze, contending that long-standing, prosperous and stable democracies (LPSDs) ${ }^{27}$ can afford the risk of hate speech, because they have ample'legal, institutional, educational and material resources to admit all viewpoints into

\footnotetext{
${ }^{18}$ See e.g. Heinze (2016), Waldron (2012), Kahn (2013).

${ }^{19}$ Schauer (2005).

${ }^{20}$ Post (1990) 632.

${ }^{21}$ Post (1990) abstract.

${ }^{22}$ 'Nothing in [the] Convention may be interpreted as implying for any State, group or person any right to engage in any activity or perform any act aimed at the destruction of any of the rights and freedoms set forth herein or at their limitation to a greater extent than is provided for in the Convention.'

${ }^{23}$ M'BalaM'Bala v. France, App no 25239/13 (ECtHR 20 October 2015).

${ }^{24}$ Glimmerveen and Haqenbeek v. theNetherlands, App no 8348/78 \& 8406/78, (ECtHR 11 October 1979).

${ }^{25}$ Norwood v. UK, App no 23131/03, (ECtHR 16 November 2004).

${ }^{26}$ For more discussion, see: https://www.echr.coe.int/Documents/Guide_Art_17_ENG.pdf

${ }^{27}$ Heinze (2016).
} 
the public discourse and yet remain adequately equipped to protect vulnerable groups from violence or discrimination'. ${ }^{28}$ Heinze presumes that hate speech would be countered not by law but by robust social activities, including strong institutional protection of minorities against discrimination, critical reflection on hate speakers at all levels of education and public discourse. With a similar logic, Barendt writes 'There may also be problems in evaluating the impact of hate speech, given that it is inevitably expressed in a society where a variety of attitudes to racial questions are held and where the government generally discourages or even outlaws racially (and religiously and other) discriminatory practices. ${ }^{29}$ (emphasis added) Thus, it appears a key limitation of free speech theories that they count with an unspoken, and perhaps unconscious, presumption that racism and xenophobia is bound to remain within boundaries, a peripheral minority and that it does not receive representation in government. They presuppose a certain level of mutual agreement between members of the society in rejecting discriminative views, at least by those social groups who hold positions and resources, so that they can shield public offices and other influential positions in society from those who represent discriminative views. This may be a typical feature of a LPSD, but still a further variable which is not included in the definition of LPSD. This 'social censorship' is explored and its potentials and threats have been examined. ${ }^{30}$

\subsection{Social censorship ${ }^{31}$}

The function of social censorship gets switched on when a discriminative ideology grips hold in the highest political leadership of a state. In democracies, elected leaders and public officials are expected to be exceptionally committed to the public good. In theory, they are furnished with political power because they are trusted to have the moral standing to be able to represent the interest of the people. Their political immunity and their obligations are regarded as a 'trade-off between strong protection for political expression and attending to the duties and responsibilities that accompany that protection'. ${ }^{32}$ Herman Hesse, the Swiss-German writer and moral philosopher, stated that The greater the power of the office, the stricter the service. ${ }^{33}$

When discriminative views start to dominate a discourse, social censorship silences those who would represent equal freedoms and dignity and those who would protect vulnerable minorities, as demonstrated by harassment of NGOs, journalists and whistleblowers in some states. In this scenario, the censors are those who represent discriminative views and not only do they limit free speech of those advocating tolerance, but confidently engage in hate speech without the fear of getting prosecuted.

\footnotetext{
${ }^{28}$ Heinze (2016).

${ }^{29}$ Barendt (2019).

${ }^{30} \mathrm{~A}$ similar, but more positively sounding expression is 'counter-speech' which is more close to what Heinze described: the open representation of the values of democracy by civil society, art, literature, entertainers and public figures, including institutions and politicians, and a brave stand-up for the protection of the rights of minorities. For the constraints of the study, this thread is not followed here.

${ }^{31}$ I use the expression of 'social censorship' in a neutra lsense, pointing at its potential to preserve democratice values aswell as to suppress liberties.

${ }^{32}$ McGonagle (2013).

${ }^{33}$ Hesse (2012).
} 
When hate speech is present at the highest level of political leadership, it cannot be expected that social censorship works against discrimination. On the contrary, the official representation of the people supports and encourages discriminative action, even against existing legal rules. Even when the legal rules of equality are still respected, a creeping social transformation begins, which derogates the operation of institutions, in particular those, which are supposed to protect the vulnerable groups. Moreover, the discriminative views are one step away from being turned into policies.

This could happen in a state with or without legal restrictions on hate speech. When things get reach this level, their enforcement will be hindered, even if there are legal restrictions, for at least two reasons.

1. hate speech laws cannot be applied because the institutionalised speech cannot be linked to one individual perpetrator e.g. billboards and public service television

2. law-enforcement agencies may have been already captured and may therefore be loyal to the government. 'The best preventive statutes are ineffective if the public officials in general, who, by controlling the key positions in the administration and by guiding the execution of the laws, are responsible for law enforcement, are not thoroughly loyal to the state from which they draw their livelihood. ${ }^{34}$

Examining closer the criteria of long-standing, prosperous and stable democracies (LPSDs), it turns out that two of these conditions are less applicable to predict resilience against hate speech. Firstly, economic prosperity is subject to sudden change. An economic crisis, or a series of crises, as seen in the 21st century Europe, can shatter the economic prosperity of states. Second, the stability of a democracy depends on a number of factors, among them the general, widespread and robust popular belief in the democratic values, an important measurable variable. ${ }^{35}$ The proliferation of discriminative views, growing hostility and polarisation are able to shatter the belief in and thus the stability of a democracy. It turns out that the 'stability' factor is not independent from the value that it is supposed to predict: social resilience towards hate speech. Rather, it is resilience which is a pre-condition of stability and not the other way around. This reduces the applicability of the theory.

Nevertheless, the idea is worth further development as it responds to the number 1 factor in the Rabat Plan of Action, and also to an important factor assessed by the European Court of Human Rights - context. The factor of 'context' means that speech act should always be placed in the particular social and political context prevalent at the time of the speech. ${ }^{36}$ The ECtHR acknowledged that states have a margin of appreciation, for the context of the speech is different from state to state (Šimunićv. Croatia, Balsyté-Lideikiene v. Lithuania, Altıntas v. Turkey, Perinçek v. Switzerland). ${ }^{37}$

\footnotetext{
${ }^{34}$ Loewenstein (1937).

${ }^{35}$ See for example: Pew Research Centre (2019) European Public Opinion Three Decades After The Fall Of Communism. 2. Democratic values. 14 October 2019. https://www.pewresearch.org/global/2019/10/14/democratic-values/. See also: Messing - Ságvári (2019).

${ }^{36}$ Parmar (2015) 229.

${ }^{37}$ Šimunićv. Croatia, App no 20373/17, (ECtHR 22 January 2019); Balsyté-Lideikienèv. Lithuania, App no 72596/01, (ECtHR 4 November 2008); Altıntaş v. Turkey, App no 50495/08, (ECtHR 10 March 2020); Perinçek v. Switzerland, App no 27510/08, (ECtHR 17 December 2013).
} 
The issue of social censorship and its mechanism should be explored and examined in the context of the new communication environment. The more rigidly structured media of the 20th century could successfully back up 'social censorship'. It warded off those who hold discriminative views from funding, office, airtime and other resources necessary for political success. The networked information society provides more equal opportunities to the minorities both vulnerable minorities and those 'viewpoint minorities' who contest the right of other minorities to equal opportunities. These have been critical of 'political correctness', which is a manifestation of the, in their view unnecessary, 'social censorship' and challenged the most basic values of societies.

In the new informational environment, politicians can gain their voters' attention without the filter of the professional media. In social media, they can show their 'uncensored' opinion, without reflections, questions, moderation or editing by the journalists who conveyed the political messages in earlier days. Commenting and liking offers the experience of interacting, without having a real formative effect on the discourse or the events. ${ }^{38}$

In this new informational ecosystem, the ranking factors of popularity are radically different from that in the legacy media system, which relied on entry barriers of financial and cultural nature. Content had been filtered by owners, publishers, editors and other media professionals before it was published. It is now clear in retrospect, how elitist that system was, enforcing the values of the upper-middle-class white males and ignoring the voices of social minorities. ${ }^{39}$ However, its social filtering function effectively moderated the tone of publicised content and warded off hate speech in the media.

Positive examples of today's hyper-plurality of opinions are the me-too movement, the Black Lives Matter movement and other movements which expose social injustice and gather the voices of the suppressed minorities in the virtual space. However, the same virtual space gives room to racist, homophobic, misogynic, etc. speakers and their opinions, which are not only published but gradually becoming the mainstream. The online space was initially regarded as an promising new marketplace of ideas which would finally give room to all ideas with equal chances, but this equality has been quickly distorted by interference of power and finances. Marketing campaigns and political representation give more weight to certain ideas than their genuine social support. Populistic politicians build on social media to a larger extent than other politicians, ${ }^{40}$ exploiting the basic fears and instincts of their electorate. ${ }^{41}$ Direct communication through the social media serves well their fake image of being 'one of the people', as opposed to the corrupt establishment. This rhetoric has a built-in disposition to discrimination the rhetoric is typically on the verge of hate speech, as signalled also by the annual ECRI reports which consecutively express concern for a steady rise of 'hate speech and xenophobic populism'. ${ }^{42}$

\subsection{Cause and effect}

The European approach to hate speech regulation will now be examined. There is a general agreement that speech which insults or offends individuals because of their protected

\footnotetext{
${ }^{38}$ Comment scan be deleted, and posts can be edited even after publishing, e.g. on Facebook.

${ }^{39}$ Bayer, Bitiukova, Bárd et al. (2019).

${ }^{40}$ Bayer, Bitiukova, Bárd et al. (2019).

${ }^{41}$ Ernst, Engesser, Büchel et al. (2017) 1350.

${ }^{42}$ ECRI (2019).
} 
characteristics, is, although reprehensible, still within the protected realm of speech as a democratic public discourse must put up with such offending statements. However, a speech that is likely to cause harm in individual rights and lead to violence, discrimination or hostility, can be restricted. This philosophy is reflected in Article 20 of ICCPR and in several of the national regulations. In legal practice, however, defining 'likelihood' is an arduous exercise - it needs a causal connection between the speech and hypothetical future events.

This principle has a tendency to generate a vicious circle of argumentation. If a speech occurred and no violence followed, then apparently the likelihood was insufficiently high and thus, most hate speakers get away from responsibility. This is the case with the Genocide Convention's applicability. Incitement to genocide is applicable only if genocide occurred; the ensuing war crimes justify in retrospect the restriction of the inchoate speech only if there was a causal relationship between the speech and the act. ${ }^{43}$ A lapse of time of one year prevented the court in establishing such relationship in the Seselj case. ${ }^{44}$

In contrast to the Genocide Convention, the Rabat Plan of Action lists 'likelihood' as factor no. 6. of its six-part test. This means that the action advocated through incitement does not need to be committed for the speech to amount to a crime - a reasonable probability of the occurrence should be enough. ${ }^{45}$ Most importantly, the Rabat Plan of Action's other five factors (context, speaker, intent, content and form, extent and magnitude of the speech) all provide guidance to establish the probability of the occurrence of a violent action. Three of the five factors are closely related: the identity of the speaker, the intent and the extent or magnitude of the speech. More specifically, all these three factors should be marked as positive when public officials or political figures express discriminative statements. First, the speaker's elevated position is likely to make the speech more impactful. Secondly, such actors are supposed to be aware that their words are likely to have resonance and it would be hard to argue that such a person did not intend or their words be followed by action. Third, the publicity that is given to persons of authority directly affect the reach, the magnitude and the size of the audience.

3.2.1. The power of speech by persons in authority. Even if the political messages formulated by the populist leaders do not reach the threshold of criminal hate speech, their repeated and consequent representation increases their effect. ${ }^{46}$ This is known as ${ }^{47}$ 'cumulative extremism' and was defined by Ferguson. Frequently repeated messages have a greater chance of being considered especially if they are not boring ${ }^{48}$ and if they come from a person with perceived authority acknowledged that official speech has a higher potential to impact the individual

\footnotetext{
${ }^{43}$ Timmermann (2006), see also: IMT (1947) Link 1.

${ }^{44}$ The same prevents Hungarian courts from establishing incitement to hatred even in straightforward cases: according to a 1992 ruling of the Hungarian Constitutional Court, the clear and present danger of immediate violation of individual rights must be established, in order to find that the speech amounted to incitement to hatred. See 30/1992. (V. 30.) Constitutional Court Decision, Hungary.

${ }^{45}$ Parmar (2015) 230.

${ }^{46}$ Frequency of the communication is included within the factor of 'extent' of the speech act in the Rabat Plan of Action, 29.e.

${ }^{47}$ Ferguson (2016).

${ }^{48}$ Isakovic (2019).
} 
rights. Barendt, while contesting that a harm to dignity alone should justify restriction, acknowledged that official speech has a higher potential to impact the individual rights. ${ }^{49}$

The power of the ideas is derived from the authority; those ordinary speakers who express their biased opinion with more heated words, feel with reason that their statements are backed by their political leader. The political power appears to legitimise the intolerant views and desensitises the neutral part of the audience - whereas at the same time, it increases animosity in the hostile group and aggravates debasement of the targeted minorities. Hate speech is more powerful when 'backed by power, authority, or threat'. ${ }^{50}$

If the discriminative views are imparted as part of an election campaign and supported with instruments of political marketing and rhetoric, they might reach an exceptionally high impact. This, according to Reid, creates such a high probability that it justifies activating the 'precautionary principle? ${ }^{51}$

The precautionary principle states that if 'we are unsure of the consequences of some phenomenon or material or process, the principle holds, we should err on the side of restriction for fear of an unknown disaster. ${ }^{, 52}$ Thus, where the risk is very high and the costs of inaction outweigh those of the preventive action, there, even in absence of firm evidence about the necessity of the preventive action, the latter should be applied. However, the precautionary principle could also be applied in favour of freedom of expression, as it was used by Mill, ${ }^{53}$ holding that the restriction of freedom of expression would be so catastrophic that it is better to err on the side of liberalism. Indeed, a disturbing contradiction can be perceived between the highest level of protection of political speech and the risk of harm caused by hate speech as a political programme.

On the one hand, the original justification for the elevated protection of political expressions has been to ensure the rational deliberation of the alternative options and the quest for the truth $\operatorname{and}^{54}$ on the other, the purpose of discriminative views is to reduce diversity, rather than increase it. Protecting such would amount to protecting abuse of right to demolish the very idea which grants them that right.

Reliance on the precautionary principle seems to be justified, unless we exactly now where the tipping point is, after which freedom of political expression does no longer serve pluralism, but foments the limitation of individuals' rights. But is it possible to identify such a preceding stage, before discriminative views become official state views but not before there is a reasonable risk of this occurring? Further research, utilising big data science in social research, could potentially predict the statistical probability when this would come. For example, guessing without scientific underpinning, when discriminative views are present in the opposition parties and are gaining social support, would there be momentum for the government to impose stricter rules to protect democratic institutions and values? What would be that 'stricter' threshold and how exactly would it be justified?

\footnotetext{
${ }^{49}$ Barendt (2019)

${ }^{50}$ Delgado - Stefancic (2009) 11-12.

${ }^{51}$ Reid (2019) 633.

${ }^{52}$ Schauer (2012) 139.

${ }^{53}$ In case that we define the catastrophe as the large-scale restriction of speech. .' See in Schauer (2009) 305.

${ }^{54}$ Mill (1863).
} 
3.2.2. The speech act theory. Hate speech scholars have identified a new line of emergent academic discourse, that relies on the linguistic speech act theory. ${ }^{55}$ This holds that speech is not merely a cause of action but is an action itself. In the context of hate speech, this means that speech acts not only cause subordination of individuals belonging to the minority, but in themselves constitute such subordination. 'Subordination' is a damage to the dignity of the persons belonging to the attacked group, but not a violation of their physical integrity. Thus, it would not reach the threshold of the ICCPR, which requires incitement to 'discrimination, hostility or violence' (Article 20(2)). It could be argued, that the violation is caused to the equal status of the attacked group of persons without regard to the subjective effect caused in the audience. The subordination would occur by speech constructing a social reality for the subordinated group, ${ }^{56}$ as perceived either by the members of the group or other members of society. This social reality is defined by unwritten social norms that determine:
a) the (relative) social status of the subordinated group
b) the rights and powers members of the group possess
c) acceptable behaviour towards those members. ${ }^{57}$

This concept is under discussion and formation but has already significantly influenced the academic discourse. ${ }^{58}$ It gains particular relevance in the perspective of hate speech expressed by persons of authority, which, according to the speech-act theory, constructs the social reality for masses of people.

The revolutionary element in this concept is that hate speech would be proscribed without having to examine the actual causal relationship to the 'hypothetical illegal behaviour of others'. This could be a great relief from the current balancing exercise, considering, that the chain of cause-and-effect between the speeches of influential actors and the violent actions of other people in society is very weak. Under the current threshold, the court has to find proven beyond reasonable doubt that the incriminate speech had the potential effect to cause another persons' illegal behaviour. In certain cases, the court would be expected to establish a cause and effect relationship between words of a person and between a hypothetical action that has not been committed by another person, but had it been committed, it would have been caused by the first person's words.

This balancing puts the threshold of restriction so high that criminal restrictions are very rarely activated, ${ }^{59}$ while at the same time, due to the frequent and authoritative expressions of discriminative views and legal hate speech, a social climate is created where the dignity ${ }^{60}$ and

\footnotetext{
${ }^{55}$ Austin (1975).

${ }^{56}$ Maitra (2012) 5.

${ }^{57}$ Maitra (2012) 5 .

${ }^{58}$ For debate, see: Barendt (2019) and Heinze (2016).

${ }^{59}$ Bayer - Bárd (2020) 21, 58, 73-74. See also: UN General Assembly (2019) 11.The difficulties of the judicial interpretation of the elements of incitement to hatred are explicitly discussed among others in Article 19 (2012) 1, and in the Hungarian Constitutional Court Decision 18/2004. (V. 25.) 3.2.

${ }^{60}$ Importantly, this harm also needs to be distinguished from violation of individual reputation, which is not a relevant factor in this case: neither the mental state of the targeted person or group member, nor the mental state of the listeners needs to be examined here.
} 
equal standing of minority groups is systematically violated. Therefore, itis argued that even expressions of hate speech which in themselves do not reach the criminal threshold of incitement to hatred, can violate fundamental rights of persons belonging to minorities, if they are systematically represented by persons in authority and thus construct new social norms - norms of inequality. For example, however subtle they are, they desensitise against everyday racism and lay the grounds for actual discrimination. Consequently, hate speech expressed in this manner, robs people of their dignity, an inalienable fundamental human right. ${ }^{61}$

\section{CONCLUSIONS}

Hate speech is the most harmful when it is expressed by persons of authority, in a 'less than prosperous and stable' community. This is exactly the situation when legal rules, legal procedures and social interventions all promise very limited improvement. In such a purely hypothetical situation, the rule of law would be shattered, discriminative views were proclaimed to be held by the majority and the consequent political representation of these violent views would exercise a chilling effect on those groups and individuals who would represent the social norms of equal rights.

While international human rights law would still be applicable, a government which disrespects human rights would also be likely to ignore the international judgements. ${ }^{62}$ Even though international court judgements may not have a deterring effect on the state which is subject to it, they give a clear signal to other members of the international community. The same could be said about speech actions e.g., court decisions, of national or local scope. Counterspeech, ${ }^{63}$ as a pro-active manifestation of social censorship, may have a significantly higher role in combatting hate speech than criminal provisions, especially if the latter are dormant.

\section{LITERATURE}

\section{ACADEMIC SOURCES}

Article 19, Prohibiting incitement to discrimination, hostility or violence (Article 19, 2012).

Austin, J. L., How To Do Things With Words (Harvard University Press 1975).

Bárd, K., 'Vizsgálat egy terven felüli (?) népirtás ügyében' (2020) 32/1 Múlt és Jövő 57-66.

Barendt, E., 'What Is the Harm of Hate Speech?' (2019) 22 Ethical Theory and Moral Practice 539-553. https://doi.org/10.1007/s10677-019-10002-0.

\footnotetext{
${ }^{61}$ Waldron (2012).

${ }^{62}$ Bayer, J. (2018).

${ }^{63}$ Bayer - Bárd (2020).
} 
Bayer, J., 'Media freedom and pluralism: legislation and enforcement at the European level' (2018) Journal of the Academy of European Law 101-3.

Bayer, J., Bitiukova, N., Bárd, P. et al., Disinformation and propaganda - impact on the functioning of the rule of law in the EU and its Member States (European Parliament Policy Department C: Citizens' Rights and Constitutional Affairs 2019).

Bayer, J. and Bárd, P., Hate speech and hate crime in the EU and the evaluation of online content regulation approaches (European Parliament, Policy Department C: Citizens' Rights And Constitutional Affairs 2020).

Delgado, R. and Stefancic, J., 'Four Observations about Hate Speech' (2009) 44 Wake Forest Law Review 353-70.

DesForges, A., 'Leave None to Tell the Story. Genocide in Rwanda', Human Rights Watch (1999) https:// www.hrw.org/report/1999/03/01/leave-none-tell-story/genocide-rwanda. Accessed 23 August 2020.

ECRI, 'Hate speech and xenophobic populism remained major concerns in Europe in 2018' (2019) https:// www.coe.int/en/web/european-commission-against-racism-and-intolerance/-/hate-speech-andxenophobic-populism-remained-major-concerns-in-europe-in-2018. Accessed 23 August 2020.

Ernst, N., Engesser, S., Büchel, F. et al., 'Extreme parties and populism: an analysis of Facebook and Twitter across six countries' (2017) 20/9 Information Communication and Society 1347-64.

Ferguson, K., 'Countering violent extremism through media and communication strategies. A review of the evidence' (2016) Partnership for Conflict, Crime and Security Research University of East Anglia.

Gordon, G., 'The Forgotten Nuremberg Hate Speech Case: Otto Dietrich and the Future of Persecution Law' (2014) 75/3 Ohio State Law Journal. http://hdl.handle.net/1811/71630.

Heinze, E., Hate Speech and Democratic Citizenship (Oxford University Press 2016).

Hesse, H., Das Glasperlenspiel (Suhrkamp 2012). https://archive.org/stream/MagisterLudiTheGlassBeadGame-HermanHesse/hesseludi. Accessed 23 August 2020.

Isakovic, Z., Introduction to a Theory of Political Power in International Relations (Routledge 2019).

Kahn, R. A., 'Why Do Europeans Ban Hate Speech? A Debate Between Karl Loewenstein and Robert Post' (2013) 41/3 Hofstra Law Review http://scholarlycommons.law.hofstra.edu/hlr/vol41/iss3/2. Accessed 23 August 2020.

Loewenstein, K., 'Militant Democracy and Fundamental Rights, II. The American Political Science Review' (1937) 31/4 638-658. Published by: American Political Science Association at: https://www.jstor.org/ stable/1948103.

Maitra, I., 'Subordinating Speech I' in Maitra, I., McGowan, M. K. (eds) Speech and Harm: Controversies Over Free Speech (Oxford Scholarship Online 2012), https://doi.org/10.1093/acprof:oso/ 9780199236282.001.0001.

Maravilla, Ch. S. (2018) 'Hate Speech as a War Crime: Public and Direct Incitement to Genocide in International Law' (2018) 17 Tulane Journal of International and Comparative Law 113-45.

McGonagle, T., 'The Council of Europe against online hate speech: Conundrums and challenges' (Council of Europe 2013) 1-37. https://rm.coe.int/16800c170f. Accessed 23 August 2020.

Melvern, L., 'Missing the Story: The Media and the Rwandan Genocide' (2001) 22/3 Contemporary Security Policy 91-106.

Messing, V. and Ságvári, B., Still Divided but More Open: Mapping European Attitudes Towards Migration before and after the migration crisis. (Friedrich-Ebert-Stiftung Regional project 'Flight, Migration, Integration in Europe' 2019) 1-41. http://library.fes.de/pdf-files/bueros/budapest/15322.pdf. Accessed 23 August 2020.

Mill, J. S., On Liberty (Ticknor and Fields, 1863). 
Parmar, S., 'The Rabat Plan of Action: A Critical Turning Point in International Law on "Hate Speech"' in Molnar, P. (ed) Free Speech (CEU Press 2015).

Pew Research Centre, 'European Public Opinion Three Decades After The Fall Of Communism. 2. Democratic values.' (14 October 2019). https://www.pewresearch.org/global/2019/10/14/democraticvalues/. Accessed 23 August 2020.

Post, R. C., 'The Constitutional Concept of Public Discourse: Outrageous Opinion, Democratic Deliberation and Hustler Magazine v. Falwell', (1990) 103/3 Harvard Law Review 603-86.

Reid, A., 'Buses and Breaking Point: Freedom of Expression and the 'Brexit' Campaign' (2019) 22 Ethic Theory Moral Practice 623-637. https://doi.org/10.1007/s10677-019-09999-1.

Schauer, F., 'The Exceptional First Amendment' in Ignatieff, M. (ed), American Exceptionalism and Human Rights (Princeton University Press 2005).

Schauer, F., 'Is It Better to Be Safe than Sorry? Free Speech and the Precautionary Principle', (2009) 36/2 Pepperdine Law Review. http://digitalcommons.pepperdine.edu/plr/vol36/iss2/3.

Schauer, F., 'Social Epistemology, Holocaust Denial and the Post-Millian Calculus' in: Herz, M., Molnár, P. (eds), The Content and Context of Hate Speech: Rethinking Regulation and Responses (Cambridge University Press 2012).

Timmermann, W. K., 'Incitement in international criminal law' (2006) 88/864 International Review of the Red Cross 1-30.

UN General Assembly: Promotion and protection of the right to freedom of opinion and expression. Note by the Secretary General (2019) A/74/486 1-23.

Waldron, J., The Harm in Hate Speech (Harvard University Press 2012).

Yanagizawa-Drott, D., 'Propaganda and Conflict: Evidence from the Rwandan Genocide' (2014) The Quarterly Journal of Economics (2014) 129/4 1947-94.

\section{INTERNATIONAL INSTRUMENTS:}

Council of Europe Recommendation No. R (97) 20 on hate speech.

ECRI General Policy Recommendation No. 15 on combating hate speech 2015.

UN CERD General Recommendation No. 35. Combating rasist hate speech 2013.

UN Report of the United Nations High Commissioner for Human Rights on the expert workshops on the prohibition of incitement to national, racial or religious hatred. Appendix: Rabat Plan of Action on the prohibition of advocacy of national, racial or religious hatred that constitutes incitement to discrimination, hostility or violence. https://www.ohchr.org/Documents/Issues/Opinion/SeminarRabat/Rabat_ draft_outcome.pdf.

UN International Covenant on Civil and Political Rights 1966.

UN Strategy and Plan of Action on Hate Speech 2019.

Universal Declaration of Human Rights in 1948.

\section{COURT DECISIONS:}

Hungarian Constitutional Court Decision 18/2004. (V. 25.). 
Hungarian Constitutional Court Decision 30/1992. (V. 30.).

Altıntaş v. Turkey, App no 50495/08, (ECtHR 10 March 2020).

Balsyté-Lideikiene v. Lithuania, App no 72596/01, (ECtHR 4 November 2008).

Glimmerveen and Haqenbeek v. the Netherlands, App no 8348/78 \& 8406/78, (ECtHR 11 October 1979).

M'BalaM'Bala v. France, App no 25239/13 (ECtHR 20 October 2015).

Norwood v. UK, App no 23131/03, (ECtHR 16 November 2004).

Perinçek v. Switzerland, App no 27510/08, (ECtHR 17 December 2013).

Simunić v. Croatia, App no 20373/17, (ECtHR 22 January 2019).

\section{LINKS}

1. International Military Tribunal (IMT) (1947) Trial of the major war criminals. https://www.loc.gov/rr/frd/ Military_Law/pdf/NT_Vol-I.pdf

2. UN International Residual Mechanism for Criminal Tribunals (IRMCT) (2016) MICT-16-99, Šešelj, Vojislav. https://www.irmct.org/en/cases/mict-16-99. Accessed 23 August 2020.

Open Access. This is an open-access article distributed under the terms of the Creative Commons Attribution 4.0 International License (https://creativecommons.org/licenses/by/4.0/), which permits unrestricted use, distribution, and reproduction in any medium, provided the original author and source are credited, a link to the CC License is provided, and changes - if any - are indicated. (SID_1) 